"Technological challenges influencing the implementation of green energy in the SME sector in KwaZulu-Natal (KZN)"

\begin{tabular}{|c|c|}
\hline AUTHORS & $\begin{array}{l}\text { Dabululwandle Memka } \\
\text { Lawrence Mpele Lekhanya }\end{array}$ \\
\hline ARTICLE INFO & $\begin{array}{l}\text { Dabululwandle Memka and Lawrence Mpele Lekhanya (2017). Technological } \\
\text { challenges influencing the implementation of green energy in the SME sector in } \\
\text { KwaZulu-Natal (KZN). Environmental Economics, 8(3), 157-164. } \\
\text { doi:10.21511/ee.08(3-1).2017.08 }\end{array}$ \\
\hline DOI & http://dx.doi.org/10.21511/ee.08(3-1).2017.08 \\
\hline RELEASED ON & Tuesday, 31 October 2017 \\
\hline RECEIVED ON & Monday, 11 September 2017 \\
\hline ACCEPTED ON & Thursday, 19 October 2017 \\
\hline LICENSE & $\begin{array}{l}(c) \text { EY-NG } \\
\text { This work is licensed under a Creative Commons Attribution-NonCommercial } 4.0 \\
\text { International License }\end{array}$ \\
\hline JOURNAL & "Environmental Economics" \\
\hline ISSN PRINT & $1998-6041$ \\
\hline ISSN ONLINE & $1998-605 X$ \\
\hline PUBLISHER & LLC "Consulting Publishing Company "Business Perspectives" \\
\hline FOUNDER & LLC "Consulting Publishing Company "Business Perspectives" \\
\hline
\end{tabular}

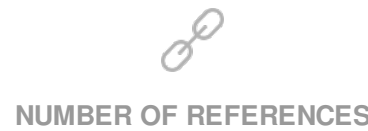

37
NUMBER OF FIGURES

0
E=-

NUMBER OF TABLES

1

(C) The author(s) 2021. This publication is an open access article. 
Dabululwandle Memka (South Africa), Lawrence Mpele Lekhanya (South Africa)

\title{
Technological challenges influencing the implementation of green energy in the SME sector in KwaZulu-Natal (KZN)
}

\begin{abstract}
Electricity is an essential basic need that the South African government needs to pay special attention. A continuous or uninterrupted supply of electricity is essential for industrial production and economic growth and development. Since South Africa is overly reliant on coal fired electricity generating technologies which are environmentally damaging, the move towards green energy technologies to form part of the electricity generating matrix is highly desirable not only to reduce environmental pollution, but also to increase the supply of electricity to meet rising demand. However, the adoption and implementation of green energy projects has not been that easy and progress has been far from satisfactory. This study was therefore consummated to assess the effectiveness of installed green technology in the area of Pinetown in Kwazulu-Natal. The study also investigated the technological challenges affecting the implementation of green energy projects in SME sector in Pinetown Kwazulu-Natal. Furthermore, the study also examined as to what extent technological challenges are affecting the use of installed green technology in the selected area of Pinetown in Kwazulu-Natal. This was followed by exploring strategies that could be implemented to improve effectiveness of installed green technology in Pinetown. A quantitative research approach was adopted. Data collection for this study was performed by distributing and collecting a structured survey questionnaire to respondents. Data analysis for this research was performed using SPSS.
\end{abstract}

Keywords: green energy, technological, implementation, SME sector, challenges, economic growth.

JEL Classification: M21.

Received on: $11^{\text {th }}$ of September, 2017.

Accepted on: $19^{\text {th }}$ of October, 2017.

\section{Introduction}

Since the later part of 2007 South Africa has experienced electricity blackouts and Eskom officially launched load shedding in January 2008. According to Chris Yelland (2014), an energy expert, controlled blackout (load shedding) in South Africa has had a negative effect on the economy. He has estimated that stage 1 load shedding for 10 hours a day for 20 days a month has resulted in losses of R20 billion per month to the economy. Using the same parameters, stage 2 load shedding would result in a R40 billion loss and stage 3 load shedding would result in an R80 billion loss per month. These costs, according to Yellend, to the productive economy are based on a cost of unserved energy of R100 per KWh. The problem emanated from the fact that South Africa has been over-reliant on coal-fired electricity generating technologies which are by an large contributing not only to electricity shortages due to limited supply, but also to environmental ground and air pollution. Yet the new world thrust is moving towards the adoption and implementation of green energy projects to serve two purposes. The first purpose is to augment electricity

(C) Dabululwandle Memka, Lawrence Mpele Lekhanya, 2017.

Dabululwandle Memka, Department of Management and Entrepreneurial Studies, Durban University of Technology, South Africa.

Lawrence Mpele Lekhanya, Department of Public Management \& Economics, Durban University of Technology, South Africa.

This is an Open Access article, distributed under the terms of the Creative Commons Attribution-NonCommercial 4.0 International license, which permits re-use, distribution, and reproduction, provided the materials aren't used for commercial purposes and the original work is properly cited. supplies and reduce load shedding and the second purpose to reduce environmental pollution.

A reliance on abundant, reliable and low-priced electricity has been a critical success factor in the business sector in South Africa. The business has in the past enjoyed one of the lowest electricity tariffs in the world (Von Ketelhodt, \& Wocke, 2008). The significance of this study would be to examine how much of a challenge it would be to implement green technology so as to mitigate the effects of load shedding in SME's and the challenges associated with the implementation green energy technology in the Pinetown area of KZN. It was predicted in Journal or Energy in Southern Africa, Volume 19, No 1 (2008) that the demand for electricity in South Africa was likely to outstrip demand and the hardest hit would be entrepreneurs and small businesses.

The predicament that South Africa found its self in was a combination of factors which are listed below (but not limited to the list below) (Cohen, M., \& Burkhardt, 2015):

- An unprecedented rollout of electricity to the masses by the new government after the inception of democracy.

- Underestimated demand coupled with economic growth that increased the need for electricity.

- Lack of investment in new generation capacity.

- Decommissioning or mothballing of power stations.

- Population growth.

- Reduced investment in maintenance.

- Loss of skills at state power utility Eskom. 
According to the Eskom website, the installed generation capacity is $44048 \mathrm{MW}$ and Eskom's total installed capacity is $44145 \mathrm{MW}$ which includes small hydro-electricity plants in the former Transkei (Generation Mix Eskom Corporate Affairs Division, 2015). There have been several notable events in the recent past that have posed a serious threat to the country's electricity supply, amongst the more notable ones were in November 2014, when a coal silo collapsed at Majuba power station and a crack was found on another silo. Majuba supplies about $10 \%$ of the country's electricity at $4116 \mathrm{MW}$ and due to the collapse the plant had to be shut down (Tripped coal stations add to load shedding burden, 2014). On Thursday $4^{\text {th }}$ November 2014 Eskom lost about 4000 MW this was due to planned and unplanned maintenance. On the $20^{\text {th }}$ November 2014 the Majuba power station shut down again as another crack was discovered on a different coal silo. On $5^{\text {th }}$ December 2014, Eskom implemented stage 3 load shedding after shutting down two power stations (Tripped coal stations add to load shedding burden, 2014). According to Yellend, when one considers that the approximate GDP for South Africa in 2014 was R4 trillion approximately $1-2 \%$ of GDP could be potentially wiped out per month as a result of load shedding

Zeta Joules (2013) has suggested the following strategies for SME have to survive load shedding.

- Do nothing.

- Buy a generator.

- Invest in a UPS or storage solution to mitigate periods of load shedding.

All of the above solutions have their advantages and disadvantages. Generators are expensive, noisy, use fossil fuels and have associated maintenance costs. According to the Business Day (10 May 2006) Cape Town as a city spent an estimate $\$ 425$ million purchasing generators due to power cuts. Doing nothing means that there would be a loss of perishable goods and sales during the power outage.

The scope of the study will move beyond how SME's survive events such as power cuts but look at the technological barriers that exist in the installation of green energy solutions. Electricity is a valuable commodity and looking at the current trajectory of electricity tariff increases the cost of electricity will continue to increase. From 2008, electricity there has been a clear and sharp increase in electricity prices far outstripping inflation, from 2007 to 2015 electricity has increased by $300 \%$, while inflation during the same period was $45 \%$, meaning that the electricity tariff tripled in 8 years (Moolman, 2015). Projecting into the future if additional increases for 2016 and 2017 were to be approved (with another 9\% per year on top of the $8 \%$ per year already approved) will take electricity tariff increases to $495 \%$ from 2007 to 2017 as compared to inflation of $74 \%$, meaning a 5-fold increase in 10 years (Moolman, 2015). SMEs have to come up with alternative strategies to get power and use the power they have effectively or as they will not be able to pass on the tariff increases to the consumer, hence a study looking into the technological barriers that exist in the implementation of green energy technology.

Problem statement. This study explicitly examined the problem of lack of progress in the implementation of green energy projects due to technological challenges. This problem is leading to increased load shedding due to shortage of adequate supply of electricity leading to a negative effect on Pinetown industrial economy and inconveniences to Pinetown residents. Though the problem of lack of progress in the implementation of green energy projects is affecting many parts of South Africa, there has not been a comprehensive study that specifically focussed on the technological challenges facing. Thus, this study endeavored to close this gap in literature by focusing on the technological challenges facing the Pinetown area in KZN.

Research aim. The aim of the study is to examine the technological challenges affecting the implementation of green energy projects in SME sector in Pinetown KwaZulu-Natal.

\section{Research objectives:}

- To assess the effectiveness of installed green technology in Pinetown area in KwaZulu-Natal.

- To investigate the technological challenges affecting the implementation of green energy projects in SME sector in Pinetown KwaZuluNatal.

- Examine as to what extent technological challenges are affecting the use of installed green technology in the selected area of Pinetown in KwaZulu-Natal.

- To recommend the strategies that could be implemented to improve effectiveness of installed green technology in Pinetown.

\section{Literature review}

\subsection{Adoption and diffusion renewable energy.}

Many people worldwide lack access to contemporary energy supply making it difficult for them to use their own efforts to get out of poverty and improve their living conditions such that allowing them access to a sustainable energy supply is the pre-requisite to reducing global poverty (Ruppel \& Althusmann, 2016). To this end, Ruppel and Althusmann (2016) argue that the promotion of efficient renewable energy technologies reduces poverty and dependency on 
costly fossil fuels, helps to achieve efficient energy production and utilization, as well as protect the environment. Similarly, Chiguvare and Chiguvare (2014) view adequate electrical energy supply as a critical driver for economic growth. This implies that due to lack of adequate energy supply, most developing countries' contribution to the world economy remains trivial, particularly those in SubSaharan Africa. Further, Chiguvare and Chiguvare (2014) argue that secure access to contemporary sources of energy enhances economic development and prosperity making reliable sources of energy imperative for better health, higher incomes, and allround progresses in the quality of life. These all-round progresses in the quality of life include healthcare, nutrition, sense of acceptance by intimate others, activities that promote relaxation and stress reduction, and the provision of clean water. Needless to mention therefore, contemporary energy aids development by availing reliable and efficient lighting, heating, cooking, mechanical power, transport, and telecommunication services (GEA, 2012). Thus, to reduce poverty, increase productivity, enhance competitiveness and promote economic growth by facilitating the growth of SMEs, availability of affordable and reliable energy sources, such as renewable energy sources is essential.

Access to modern energy by countries in Sub-Saharan Africa (including South Africa) is exceptionally low as compared to other countries in the world and there are no sufficient efforts by the locals to deal with this inadequacy (IEA, 2014). Additionally, while there are discourses over the appropriate definition of the phrase modern energy access, the Africa Energy Outlook (2014) defines it as:

- Household access to a minimum level of electricity.

- Household access to safer and more sustainable (as less harmful effects on health and the environment as possible) cooking and heating fuels and stoves.

- Access to modern energy that enables productive economic activity (mechanical power for agriculture, textile and other industries).

- Access to modern energy for public services, (electricity for health facilities, schools and street lighting).

Basing on this definition, the Africa Energy Outlook (2014) views a government which is concerned about the welfare of its citizenry as one that makes resolute efforts towards increasing access levels, reliability and affordability of energy, as well as ensuring environmental sustainability. In this regard, Africa Energy Outlook (2014) argues that involvement of Sub-Saharan African countries in the world economy is lagging behind because African nations' participation in the development energy sources is determined by sympathetic nations from America, Europe and Asia. Kinne (2014) reveals that collaborative activities are being implemented at the level of the EU, World Bank and regional development banks in order to ensure that support in the energy sector results in strategic partnerships with developing countries. A decisive factor that has a bearing on the outcome of foreign investors' decision making processes in renewable energy projects is the long term energy security that allows the investors to offer a leading edge in renewable energy technologies (Stiftung, 2015). Accordingly, foreign direct investment into renewable energies and the proficient use of up-to-date energy solutions require a favorable regulatory and public policy framework coupled with effective upholding of existing investment protection agreements (Chiguvare \& Chiguvare, 2014). Besides these regulatory aspects, the lack of an economically viable feed-in tariff and the cap on the share of renewable energies in developing countries' future power generation are considerable barriers which impede the adoption and diffusion of renewable energy technologies in developing countries (Ruppel \& Althusmann, 2016).

1.2. Renewable energy technological challenges. Xiarchos and Lazarus (2013) observe that investments in renewable energy technologies are motivated by economic, security and environmental concerns such that extended generation of renewable electricity is intended to meet increased energy security, reduced risk from unstable energy costs and decreased emissions of pollutants into the environment. The Energy Information Administration (EIA) (2012) indicates that the cost of using renewable energy systems is considerably prohibitive even though through policy support and technological advances there has been incredible developments in new renewable capacity in some countries. However, EREC (2011, p. 64) reveals that renewable energy developments incentive systems are suffering drastic restructuring due to economic downturns being experienced by many countries. This uncertainties and insecurities in the renewable energy market, which is also severely hindering investments in this sector.

Looking from a technological perspective, Dragoman (2014) identifies access to the grid to allow for the exporting of electricity generated to the consumers, particularly SMEs as a challenging factor that affects many forms of renewable energy development. For instance, EREC (2011) reveals that in Italy, the grid does not have enough capacity to support a large number of requests from renewable energy projects and this happens frequently in remote areas where most SMEs' operations are located. Hence, the fact that SMEs' electricity market structures differ from one country to the other mainly due to historical 
reasons presents yet another technological challenge in that their energy requirements cannot be standardized. It is therefore imperative to ensure that the grid can support generated electricity supply or that there is necessary investment to secure the connection to the grid prior to commencing a renewable energy project (Balcombe, Rigby, \& Azapagic, 2013). However, the building of new infrastructure to support small projects, particularly SMEs related projects that are not capital intensive and whose returns are very minimal may be considered too expensive by many policy makers especially in governments of developing countries (EIA, 2012).

There are some advantages of developing small scale renewable energy projects that may be used to supply SMEs with electrical power. They do not require expensive upgrades of the grid or cause grid voltage overloads and, in some cases, they can be used as independent or standalone energy sources that are detached from traditional energy supply routes (Dragoman, 2014). In addition, Dragoman (2014) posits that small scale renewable energy projects that are independent from a centralized energetic system provide members of the project (SMEs) with freedom to pursue their best interests that fit their locality. Furthermore, Balcombe, Rigby, and Azapagic (2013) espouse that adopting renewable energy technology that facilitate the implementation of small scale renewable energy projects improves management of local energy demands. However, a major challenge associated with some small scale renewable energy projects is that it is difficult to install and maintain the installations especially where a group of SME's is sharing the facility. In this regard, EIA (2012) observes that too much maintenance requirements, difficulties in installing the technology and failure to add value to some SME's' businesses constitute considerable barriers towards adopting renewable energy technology. In addition, Smith, Fressoli, and Thomas (2012) note that an additional challenge of deploying renewable technology is the lack of trained personnel or readily available human capital.

1.3. Wind energy technological challenges. While wind power is the fastest-growing major energy source, Bergek and Jacobsson (2014) reveal that the scarcity of wind turbine components has resulted in increases in installation costs which present a critical challenge to SME's particularly in the developing world where foreign investment plays a significant role in the implementation of development initiatives. In this regard, Bergek and Jacobson (2014) indicate that the shortage of wind turbines which emanates from lack of their adequate production capacity has resulted in unaffordable increases in installation costs from approximately $\$ 1,100$ to the current price of $\$ 1,500$ in the United States of America. Hence, even though, the American Wind Energy Association
(2015) estimates that an expansion of installed wind power of $20 \%$ per annum from the year 2002 to 2020 will convert to 1,200 Giga Watts of wind power electricity in the world representing $18 \%$ of the total electricity supply, hopes of realizing such a significant benefit through the usage of wind power energy by SME's are uncertain due to the limited production capacity for wind turbines and the prohibitive cost of installation.

1.4. Solar energy technological challenges. Solar energy which produces electricity using the sun's rays and semiconductor chips requires power storage devices that are extremely exorbitant for the SMEs to have access to electrical power during the night (Burr, 2015). Additionally, in the views of Birgisson and Petersen (2016), solar panel technology is still extremely uneconomical at changing solar energy into considerable amounts of useable electricity, regardless of the fact that its installation can be decentralized to individual household units. Boyle (2014) indicates that a study by the New Jersey Board of Utilities reveals that installation costs of a $10 \mathrm{kw}$ capacity system in a home was $\$ 77,500$ and that the payback period for the initial investment based on current electricity prices was estimated at 50 years. the cost of using this technology in generating electricity is estimated to be three times higher than that of coal generation such that, given the opportunity to choose a source of energy, most SME's would prefer the cheaper coal generation alternative. According to Geller (2013) who indicates that this technology is used to generate only $6 \%$ of the electricity generated by solar energy and used in Asian countries, there is a need for the provision of subsidies in the development of the new technology until production costs are comparable with prices of energy produced using traditional methods and affordable to SMEs. Technological challenges of solar energy sources are compounded by a notable increase in the price of silicon input materials that exacerbates the affordability challenges being faced in the usage of solar panels by SMEs. Production of solar panels requires more silicon than that required in the computer chip industry causing disparities between the demand and supply of silicon and upward fluctuations in its prices (Ferrey, 2016). Thus, by the time the solar panel is ready for the market, many SMEs cannot afford its price and this negatively challenges green energy consumption by the SMEs.

\subsection{Biomass energy technological challenges.}

Biomass produces the largest amount of electricity by burning plant or waste material, or collecting and burning landfill gas, in the United States of America when compared with the combined amount of electricity produced using wind, solar and geothermal energy sources. In this regard, Bolinger, Wiser, and Fitzgerald (2015) observe that private companies produce biomass by making use of forest materials in 
the production of lumber such that their plants are much smaller than fossil fuel plants. Because of the biomass plants' smaller capacity, the initial expenditure on equipment is relatively higher as compared to power output and this is stands out to be prohibitive challenge to SME's who may want to adapt this source of electricity supply (Bolinger, Wiser, \& Fitzgerald, 2015).

1.6. Geothermal energy technological challenges. Geothermal energy utilizes heat trapped under the ground to generate electricity such that the major challenge that faces SME's in exploiting this source of energy is related to the drilling into the ground and capturing of the steam and heated water that is trapped underground and use that to spin turbines to generate electricity (Energy Information Administration, 2015). Additionally, the Energy Information Administration (2015) states that geothermal sites vary considerably depending on field size, water pressure, temperature, and the rate at which the field can heat and release hot water such that the proper balancing of the amounts of water taken out and put back can present a stifling challenge to SMEs wanting to use geothermal power.

1.7. Renewable energy socio-technologic challenges. Development and diffusion of renewable energy technologies hinge on policy implementation and monitoring such that the integration of renewable energy technologies into the power mix available to SME's faces challenges associated with weak institutional framework, poor policy implementation, and lack of awareness (Eleri et al., 2012). For instance, lack of political will and unsupportive regulatory framework can stifle the development and diffusion of RETs in a country thereby depriving SME's access to readily available renewable energy sources. Additionally, IEA (2012) espouses that the perennial dominance of fossil based energy sources in an economy is also a critical social challenge faced in the development and diffusion of renewable energy technologies that may ensue in their low integration and uptake by SMEs. Busch and McCormick (2014) assert that there is a need by governments to harmonize renewable energy technology laws, policies and guidelines in order to divert efforts and resources towards renewable energy technologies and focusing on high potential renewable energy sources such as solar, biomass and hydropower. Furthermore, there is a need to prioritize policy implementation and monitoring by government agencies mandated with renewable energy technologies in the country to effectively create a favorable environment required for the formation of markets, mobilization of resources and creation of legitimacy for renewable energy technologies in the economy (Busch \& McCormick, 2014). In explaining the diffusion of renewable energy technologies, Pohl and Mulder (2013) indicate that lack of implementation of economic and regulatory instruments coupled with low per capita income are some of the challenges faced in the adoption and diffusion of renewable energy technologies. In other words, Pohl and Mulder (2013) assert that the distribution of renewable energy technologies for electricity production can be sped up through the operation of economic and regulatory instruments in favor of renewable energy technologies.

1.8. Adoption and diffusion of renewable energy in South Africa. The Department of Energy (2014) perceives energy infrastructure as the basis for economic development growth in South Africa and recognizes investment in renewable energy infrastructure as a priority in South Africa's economic development and planning frameworks. The belief behind this notion is that long-term infrastructure development programs that leverage investment and participation by the private sector stimulate national growth and drive job creation through the strengthening of commercial and SMEs' activities that, hence, positively affect economic growth (UNCTAD, 2015). To this end, the Department of Energy (2014) posits that investment in renewable energy sector infrastructure is a flagship programme for South Africa's renewable energy development strategy. In contemporary economies, sustainable, clean, reliable and affordable energy supply is a crucial component in economic and socio-economic growth and development as evidenced by the severe electricity supply constraints faced in 2008 in Sub-Saharan Africa (UCT, 2015). Additionally, the Department of Energy (2014) acknowledges that during the year 2008, long-standing under investment in South Africa's energy sector exposed the country to the considerable risk of economic instability and failure to achieve developmental goals of the country. Hence, UNEP (2015) observes that the realization by the South African government that the energy sector was significantly undercapitalised has prompted the introduction of the Renewable Energy Independent Power Producer Procurement Programme (REIPPPP) aimed at rapidly opening large scale investment in renewable energy generation infrastructure development.

\section{Research methodology}

This research adopted the quantitative research methodology. 124 questionnaires were distributed to the target respondents for data collection. Questionnaires were made up with close ended questions which were distributed to the selected SMEs owners or managers.

2.1. Target population. The target population for this study were 124 business owners/managers operating in the Pinetown area of Kwazulu Natal province. 
2.2. Sampling. The sampling for this study involved the selection of 124 existing employees of SMEs in the green energy sector in the Pinetown area The rationale for adopting the sampling of employees involved in the installation og green energy projects lay in the fact that the researcher was limited by time and costs as constraints that made it impossible to interview everyone. This sampling of respondents resonated with the assertions by Landerau (2010) who similarly agreed that where larger numbers of respondents exists, it is virtually impossible to interview or survey everyone.

2.3. Data collection tools. This research purely utilized the 5 point Likert scale questionnaire as a data collection tool. The researcher distributed questionnaires to the individual businesses premises and the respondents were given 3 days to complete the questionnaire and were later collected by the research for data cleaning and capturing.

2.4. Data analysis methods. Statistical Package for the Social Sciences (SPSS) Version 24.0 was chosen to analyze the data collected. Since SPSS is compatible with Microsoft Excel, data inputted from Excel was exported into SPSS as variable names and coded responses. A distribution of responses was generated for the survey items as frequencies, means, and standard deviations were computed (Razali \& Wah, 2011).
2.5. Reliability, validity and trustworthiness. The reliability of information collected was ensured by exercising extreme caution so much so that only completed questionaires from persons who indicated that they are over-indebted were included in the formulation of the findings. Furthermore, the trustworthiness of the data was ensured by targeting existing management and employees of SMEs of green energy companies in KZN Durban area in order to come up with valid conclusions as to the technological challenges facing SMEs in the green energy sector in KZN Durban area, as well as intervention strategies for minimizing the impact of the technological challenges. More so, the validity of the findings was ensured through carrying out a re-check pertaining to whether data collected from primary research were correctly transcribed and included in the findings.

\section{Findings of the survey}

As indicated in the previous section that a comprehensive literature review was conducted in order to establish problem experienced by SME in implementing green energy through the use of technology. 124 owners/managers in the selected places $(\mathrm{N}=124)$ completed questionnaires were received and captured and, then, analyzed. Therefore, the following are the key findings revealed by the survey.

Table 1. National green energy programs

\begin{tabular}{|l|c|c|c|c|c|}
\hline \multicolumn{1}{|c|}{ Statement } & $\begin{array}{c}\text { Strongly } \\
\text { agree } \\
1\end{array}$ & $\begin{array}{c}\text { Agree } \\
2\end{array}$ & $\begin{array}{c}\text { Neutral } \\
3\end{array}$ & $\begin{array}{c}\text { Disagree } \\
4\end{array}$ & $\begin{array}{c}\text { Strongly } \\
\text { disagree } \\
5\end{array}$ \\
\hline $\begin{array}{l}\text { Do you think implementing of effective incentives would stimulate demand } \\
\text { for green energy? }\end{array}$ & $12(9.7 \%)$ & $65(52.4 \%)$ & $42(33.9 \%)$ & $5(4.0 \%)$ & \\
\hline $\begin{array}{l}\text { Do you think a significant reduction in the cost of green energy products } \\
\text { like solar water heaters and PV panels would increase the demand for } \\
\text { these products? }\end{array}$ & $8(6.5 \%)$ & $69(55.6 \%)$ & $39(31.5 \%)$ & $8(6.5 \%)$ & \\
\hline $\begin{array}{l}\text { Do you think long-term industrial growth can be archieved via green } \\
\text { energy initiatives? }\end{array}$ & $14(11.3 \%)$ & $64(51.6 \%)$ & $40(32.3 \%)$ & $6(4.8 \%)$ & \\
\hline $\begin{array}{l}\text { Do you think South Africa can develop an export market within Africa for } \\
\text { green energy products? }\end{array}$ & $12(9.7 \%)$ & $71(57.3 \%)$ & $36(29.0 \%)$ & $3(2.4 \%)$ & $1(0.8 \%)$ \\
\hline $\begin{array}{l}\text { Do you think a reduction on reliance on imported system and parts would } \\
\text { assist in the proliferation of green energy and green energy products? }\end{array}$ & $12(9.7 \%)$ & $66(53.2 \%)$ & $44(35.5 \%)$ & $1(0.8 \%)$ & \\
\hline $\begin{array}{l}\text { Do you think the development of economies of scale in the local } \\
\text { production would assist in growing the green energy sector? }\end{array}$ & $10(8.1 \%)$ & $72(58.1 \%)$ & $40(32.3 \%)$ & $1(0.8 \%)$ & \\
\hline PV solar system for lights & $11(8.9 \%)$ & $72(58.1 \%)$ & $36(29.0 \%)$ & $4(3.2 \%)$ & \\
\hline Solar geyser & $11(8.9 \%)$ & $61(49.2 \%)$ & $50(40.3 \%)$ & $1(0.8 \%)$ & \\
\hline Energy efficient LED lights & & & & & $8(6.5 \%)$ \\
\hline Energy efficient air conditioning & $12(9.7 \%)$ & $49(39.5 \%)$ & $52(41.9 \%)$ & \\
\hline
\end{tabular}

The above table shows that implementing of effective incentives would stimulate demand for green energy, (12 (9.7\%) and $65(52.4 \%)$ agreed with the statement). A significant reduction in the cost of green energy products like solar water heaters and PV panels would increase the demand for these products $(8(6.5 \%)$ and $69(55.6 \%)$ agreed with the statement). Long-term industrial growth can be archieved via green energy initiatives (14 $(11.3 \%)$ and $64(51.6 \%)$ agreed with the statement). South Africa can develop an export market within Africa for green energy products (12 (9.7\%) and 71 (57.3\%) agreed with the statement). A reduction on reliance on imported system and parts would assist in the proliferation of green energy and green energy products (12 (9.7\%) and $66(53.2 \%)$ agreed 
with the statement). The development of economies of scale in the local production would assist in growing the green energy sector $(10(8.1 \%)$ and 72 (58.1\%) agreed with the statement).

\section{Implementation}

(In your opinion, which of items below would you deem important when implementing green energy in your business).

The table above shows that PV solar system for lights $(11(8.9 \%)$ and $72(58.1 \%)$ agreed with the statement), solar geyser $(11 \quad(8.9 \%)$ and $61(49.2 \%)$ agreed with the statement), energy efficient air conditioning (12 (9.7\%) and 49 $(39.5 \%)$ agreed with the statement).

\section{Limitations}

This study did not cover all provinces in South Africa and was confined to specific area in the province of KwaZulu-Natal. The findings of this survey cannot be generalized to South Africa but rather can be used as the point of reference. Due to the complexity and dynamics of South African environment including economic conditions, as well as social attrributes, further research needs to cover big business as well.

\section{Recommendations}

The fundings of the survey suggest that technological challenges influencing the implementation of green energy in the SMEs sector in KZN. Therefore, this study recommends that introduction of the use technology by SMEs and technical support, as well as financial support should be provided by all relevant stakeholders for this sector. This research also recommend that policy makers should encourage the use the implentation of green concepts in all sectors of business and within the communities. The innovation of green zone in the SME sector should be enforced by the authorities.

\section{Conclusion}

Strong understanding of related factors affecting technological challenges influencing the implementation of green energy in the SME sector in KZN and its implcations are of prime impotrtance. This survey concluded that technology can bring and make it easy for SMEs to use green products and reduce their day-to-day operating cost significantly while realizing growth and sustainable development. It has been indentified that lack of implementation, lack of awareness of the benefit of technology in bring green products in the SMEs is the major stumping block for the growth of SMEs sector.

\section{References}

1. Balcombe, P., Rigby, D., Azapagic, A. (2013). Motivations and barriers associated with adopting microgeneration energy technologies in the UK. Renewable and Sustainable Energy Reviews, 22, 655-666.

2. Birgisson, G., \& Petersen, E. (2016). Renewable Energy Development Incentives: Strengths, Weaknesses, and the Interplay. The Electricity Journal, 19(3), 40-51.

3. Bolinger, M., \& Wiser, R., Fitzgerald, G. (2015). An Overview of Investments by State Renewable Energy Funds in Large-Scale Renewable Generation Projects. The Electricity Journal, 18(1), 78-84.

4. Boon, F. (2012). Local is beautiful, The emergence and development of local renewable energy organizations, Master Thesis, Utrecht University - Faculty of Geosciences.

5. Boyle, G. (2014). Renewable Energy: Power for a Sustainable Future. Oxford University Press.

6. Burr, M. (2015). Windpower: Beyond Boom and Bust. Public Utilities Fortnightly, 28-35.

7. Busch, H., McCormick, K. (2014). Local power: exploring the motivations of mayors and key success factors for local municipalities to go $100 \%$ renewable energy. Sustainability and Society, 4-5. Retrieved from http://www.energsustainsoc.com/content/4/1/5

8. Bhattacherjee, A. (2013). Social Science Research: Principles, Methods, and Practices. Textbooks Collection. Book 3. University of South Florida Tampa, Florida, USA.

9. Burns, R., \& Grove, S. (2011). Introduction to Research Methods. London: Sage.

10. Bomberg, McEwen (2012). Mobilizing community energy. Energy Policy, 51, 435-444.

11. Chiguvare, K., \& Chiguvare, J. (2010) The challenges of Promoting Sustainable Energy in Southern Africa. Retrieved from http://jornades.uab.cat/sustainableafrica/content/speakers

12. Cohen, M., \& Burkhardt, P. (2015). Bloomberg Business, Once Lauded Eskom Now derided over south African power cuts. Retrieved from http://www.bloomberg.com/news/articles/2015-06-07/once-lauded-eskom-nowderided-over-south-african-power-outages

13. Corporate Affairs Division, Messaging Desk, Eskom Presentation (2015). Load Shedding Understanding Facts. Retrieved from http://www.eskom.co.za/sites/idm/Pages/Home.aspx

14. Creating a better tomorrow, one joule at a time. (2013). Retrieved from http://www.1zettajoules.com/load_shedding_shedding_for_sme.html

15. Creswell, J. W. (2013). Research design: Qualitative, quantitative, and mixed methods approach (Second Edition). Thousand Oaks, SAGE Publications, Inc.

16. Dragoman, M. C. (2014). Factors influencing local renewable energy initiatives in different contexts. Comparative analysis: Italy, Romania and the Netherlands. University of Twente. 
17. Eskom (2009). Fact Sheet Demand side management, Power conservation program and internal energy efficiency. Retrieved from http://www.eskom.co.za/annreport09/ar2009/info sheets/index.htm

18. European Renewable Energy Council (2011). Mapping Renewable Energy Pathways towards 2020, EU ROADMAP. Retrieved from http://www.repap2020.eu/fileadmin/user_upload/Roadmaps/EREC-roadmapV4_final.pdf

19. Generation Mix Corporate Affairs Division, Messaging Desk, Eskom Presentation (2015). Retrieved from http://www.eskom.co.za/sites/idm/Pages/Home.aspx

20. Energy Information Administration (2015). Policies to Promote Non-hydro Renewable Energy in the United States and Selected Countries.

21. Ferrey, S. (2016). Renewable Orphans: Adopting Legal Renewable Standards at the State Level. The Electricity Journal, 19(2), 52-61.

22. Gray, G., \& Guppy, N. (2014). Successful surveys: Research methods and practice (4th ed.). Toronto: Harcourt Canada.

23. Hielscher, S. (2013). Community energy: a review of the research literature in the UK, SPRU (Science and Technology Policy Research), University of Sussex, Brighton.

24. Johnson, B., \& Christensen, L. (2010). Educational Research: Quantitative, Qualitative, and Mixed Approaches. UK: SAGE.

25. Kothari, C. R. (2012). Research Methodology: Methods and Techniques. Wiley, Eastern, New Delhi, India.

26. Konrad-Adenauer-Stiftung. (2015). International Report on Resources. Energy and Law, 1/15. Retrieved from http://www.kas.de/wf/doc/kas_40185-544-2-30.pdf?150126095215

27. Kinne, U. (2014). Aspects of Germany development policy in energy issues. Namibia: Macmillan Education.

28. Lenderau, K. J. (2010). Sampling strategies. San Francisco: University of California.

29. Mason, J. (2011). Making Convincing Arguments with Qualitative Data (pp. 173-204). Qualitative Researching. London: Sage.

30. Miles, M. B., \& Huberman, M. (2011). Qualitative Data Analysis: A Sourcebook of New Methods. Beverly Hills: Sage Publications.

31. Smith, A., Fressoli, M., \& Thomas, H. (2014). Grassroots innovation movements: challenges and contributions. Journal of Cleaner Production, 63, 114-124.

32. Mohammed,Y., Mustafa, M. W Bashir, N., \&. Mokhtar, A. S. (2013). Renewable energy resources for distributed power generation in Nigeria: a review of the potential. Renewable and Sustainable Energy Reviews, 22, 257-268.

33. Pascal Abb (2013). China's Foreign Policy Think Tanks: Changing Roles and Structural Conditions (Working papers). Germany Institute of Global and Areal Studies.

34. Piergiorgio, C. (2013): Social Research Theory, Methods and Techniques. Data. London: Routledge.

35. Pohl \& Mulder. (2013) Renewable energy in South Africa: potentials, barriers and options for support. Energy Policy, 38(9), 4945-4954. http://dx.doi.org/10.1016/j.enpol.2010.03.077

36. Xiarchios, I. M., \& Lazarus, W. (2013). Factors affecting the adoption of wind and solar generating systems on US farms. Experiences at the state level. United States Department of Agriculture.

37. Wilson, I. M. (2010). Sampling and Qualitative Research. Theme Paper for DFID. Retrieved from www.reading.ac.uk/ssc/ 